\title{
REALIDADE SINTÉTICA: HISTÓRIA, PATRIMÔNIO E MEMÓRIA NA ARTESANIA DE UMA IDENTIDADE URBANA $^{1}$
}

\author{
João Batista Bitencourt*
}

\begin{abstract}
Resumo: O presente artigo busca analisar o discurso oficial de cidade histórica empregado ao município de Laguna, Santa Catarina. Apresenta e discute elementos utilizados para compor esta imagem para a cidade, promovendo um exercício de estranhamento à identidade que transforma sua história em mercadoria para o turismo.
\end{abstract}

Palavras-chave: História. Patrimônio. Identidade.

\begin{abstract}
This article seeks to analyze the official discourse of historic city employee of the municipality of Laguna, Santa Catarina. Introduces and discusses the factors used to compose this image for the city, promoting an exercise of strangeness to the identity that transforms its history in goods for tourism.
\end{abstract}

Keywords: History. Heritage. Identity.

\footnotetext{
* Professor no Programa de Pós-Graduação em História da Universidade Federal do Maranhão (UFMA). E-mail: bitencourt.jb@gmail.com
} 
"Laguna, pelas belezas naturais, suas praias famosas e acolhedoras, lagoas piscosas e pelo seu patrimônio histórico e cultural, transformou-se no Pólo Turístico da Região Sul”.

De um folheto da Pref. M. de Laguna, 1982

"O que todos os símbolos sagrados afirmam é que o melhor para o homem é viver de modo realista - onde eles diferem é na visão da realidade que constróem".

Clifford Geertz

"Bom dia minha gente! Olha a hora que é muito importante para quem vai viajar, trabalhar ou estudar: são sete horas na capital histórica de Santa Catarina". ${ }^{2}$ Nos últimos anos os radiouvintes da Garibaldi vêm sendo despertados desta forma. Assim, começa o programa Show do rádio levado ao ar diariamente às sete horas da manhã, na voz de João Manoel Vicente. Começa o programa e também, pode-se dizer, o dia do "amigo radiouvinte" e é assim logo nas primeiras horas do dia que o ouvinte do Show do rádio ratifica sua identidade. Mais do que identificar a espacialidade, afirmando geograficamente que se está em Laguna, a abertura do programa confirma uma identificação cultural. O radiouvinte não precisa ouvir o nome da cidade, pois a percepção passa por reconhecer sua tradição, sua especificidade, sua singularidade identificadora onde mora sua importância. Por isso, o locutor anuncia todas as manhãs que se está na "capital histórica de Santa Catarina" e o faz com tamanha ênfase que repete a cada vez que informa as horas, o que ocorre em média a cada dez minutos.

Há, do ponto de vista do enunciado do discurso, uma lógica que facilita a absorção da enunciação identitária. Tanto na abertura do programa como nas várias repetições no decorrer dele é estabelecida uma ligação entre tempo e espaço. Logo depois de dizer as horas, repete-se o "na capital histórica de Santa Catarina". O espaço não é caracterizado de forma geográfica, mas na forma de identidade cultural e isso reafirmado várias vezes durante o programa de forma imutável. Enquanto o horário necessariamente muda de uma anunciação a outra, o referencial de localização permanece igual em todas as repetições, 
fazendo com que a identidade sempre reafirmada seja absorvida de forma mais eficaz, pois mesmo que o radiouvinte tenha maior interesse nas horas, sempre irá juntamente ouvi-lo.

A abertura do Show do rádio não é uma voz solitária a afirmar uma identidade para a cidade de Laguna, ela é mais um dos muitos fios de uma tessitura social enraizada e confirmada de várias maneiras, constituinte e constitutiva de uma memória social, tão difundida como realidade ontológica que passa a figurar como natural. Há na cidade uma rede de representações, de construções simbólicas e discursivas que confluem para a visibilidade da "capital histórica", há uma percepção induzida, deliberadamente revelada. Esta teia pode não ter sido intencionalmente articulada em todos os seus fios, não foi necessariamente pensada e racionalizada numa combinação de todas as suas manifestações e dificilmente se encontrará na atualidade a congregação de seus mentores confabulando sobre seus desdobramentos. Parece que as afirmações desta identidade são tanto os frutos do que tentam convencer, quanto o próprio material constante delas, compondo-se pela interação, pela circularidade de discursos e projetos diferenciados, esta formação discursiva na medida em que cria uma tradição, caminha por outra já instaurada. Exemplo disso é que João Manoel Vicente diz que a abertura de seu programa fez-se "naturalmente", "de repente surgiu" tão espontâneo e oriundo da realidade que, da forma como coloca, parece seguir a ordem natural das coisas. ${ }^{3}$

Não se quer negar a persuasão e os interesses, o jogo de poder, contidos nessas afirmações, pois sabe-se que "as representações do mundo social assim construídas, embora aspirem à universalidade de um diagnóstico fundado na razão, são sempre determinadas pelos interesses de grupo que as forjam". ${ }^{4}$ Apenas quer-se atentar para o fato de tratar-se de uma realidade aprendida, apreendida, reelaborada e comunicada em que se justapõem representações diversas que se conectam numa rede, porém, sem que tenham um único núcleo emissor, sem precisar de uma articulação externa, não há uma reunião de todas para direcionar um caminho. Em uma palavra, não existe planejamento. As conexões dão-se pelos interesses já embutidos nas próprias afirmações, elas não precisam de plano. As configurações sociais quanto à visão sobre cidade que elas carregam é que as fazem coligadas, mesmo sem serem fabricadas na mesma máquina. Trata-se, então, de um interdiscurso que perpassa todas estas representações e que as extrapola e que na formação discursiva atual instaura a imagem de cidade histórica para Laguna e a concebe como "pólo turístico".

Assim, tem-se na atualidade um discurso autorizado sobre a cidade, fundamentado num interdiscurso. ${ }^{5}$ Não é algo que obscurece a realidade, um véu nebuloso que impede de enxergar o real, mas uma construção que se faz crer enquanto real, um discurso que cria o real, que se coloca como a própria realidade. Um discurso que tenta coincidir as palavras às coisas, que lhe apaga 
e cria história, dá-lhe significados acima dos tempos, "fora do tempo", numa razão universal globalizadora e unificadora, que tenciona compreender a todos, pois se coloca como única ou a possível. É um discurso coercitivo, operando sob a imagem da neutralidade e da verdade transcendente, "mesmo e sobretudo quando a coerção não esteja imediatamente visível por ter-se transformado em consenso invisível e interiorizado". 6

Faz-se, pois, necessário um exercício de estranhamento ao "consenso invisível e interiorizado", desnaturalizá-lo, fugir dele para percebê-lo. Como lembra M. Foucault: "é preciso que nos inquietemos diante de certos recortes ou agrupamentos que já nos são familiares". ${ }^{7}$ Uma vez que se trata de um jogo que oculta e mostra: visibiliza uma realidade, objetiva uma virtualidade, permite uma percepção para que a coerção e as relações de orquestração deste real se invisibilize, se torne o próprio real na conformidade do consenso interiorizado. Enfim, que perca sua aparência de construção, de possibilidade realizada, de escolha e opção de alguns.

Esta tessitura é a compreensão das ramificações de uma formação discursiva presente, de uma apresentação do mundo social na Laguna da atualidade, mas que, utiliza imagens discursivas forjadas em outros momentos, para determinados fins e projetos, e com estas nominações já construídas sustenta sua autoridade. ${ }^{8}$ Ao contrário de uma visão de sucessão e prosseguimentos, vê-se na história lagunense que atualmente lhe faz ser "pólo turístico da região sul", uma singular existência. Não que os elementos de sua história não sejam encontrados em outras épocas, mas hoje eles ganham novos contornos. Mesmo que se repitam as mesmas palavras e até as mesmas frases, o enunciado discursado é correlato de outra prática, remete à outra enunciação. Pois, é necessário "substituir o tesouro enigmático das 'coisas' anteriores ao discurso pela formação regular dos objetos que só nele se delineiam". ${ }^{9}$ É a compreensão dos recortes e das descontinuidades; não existe uma "condição histórica" $" 10$ lagunense através dos tempos.

Laguna é uma cidade histórica na classificação de sua urbanidade. Diferente das cidades pensadas nas pranchetas, esquadrinhadas e quadriculadas, dos arquitetos modernos. ${ }^{11}$ No entanto, não devemos esquecer que os imaginários se expressam nas mais diferentes linguagens e, mesmo o traçado urbano e a arquitetura cumulativa de uma cidade que guarda seus passados, fazem-se depositários de formulações imaginativas. Como lembra Bronislaw Baczko: "todas as cidades são, entre outras coisas, uma projeção dos imaginários sociais no espaço". ${ }^{12}$

O tombamento pela União em 1985, que transformou o centro de Laguna em parte integrante do patrimônio histórico nacional, garantiu por completo a manutenção de sua paisagem urbana pela preservação de seu 
acervo arquitetônico e paisagístico. Algumas construções, exemplos de sua "arquitetura riquíssima", já haviam tornado-se objeto de tombamento por lei municipal de 1975 e sucessivos decretos, nas administrações dos prefeitos Francisco de Assis Soares e Mário José Remor. Esta legislação colocava os bens que passaram a fazer parte do "patrimônio histórico, artístico e cultural do município" sob a tutela do Conselho Municipal de Cultura, criado um ano antes pela lei $n^{\circ} 28$ de 23/09/74. ${ }^{13}$ Também o museu Anita Garibaldi já fazia parte do patrimônio histórico nacional desde a década de cinqüenta, quando foi comemorado o primeiro centenário da comarca de Laguna. ${ }^{14}$ Este acervo destinado a preservação expressam, segundo Alcídio Mafra de Souza, autor de um guia sobre os bens tombados em Santa Catarina, uma edição "determinada" pelo governador Vilson Pedro Kleinübing, "uma continuidade da evolução histórica no que concerne ao núcleo urbano original". ${ }^{15}$

A historiografia recente tem muito discutido as questões urbanas e, principalmente, atentado para a polifonia das metrópoles, procurando ver "alguns dos procedimentos - multiformes, resistentes, astuciosos e teimosos - que escapam à disciplina sem ficarem mesmo assim fora do campo onde se exerce, e que deveriam levar a uma teoria das práticas cotidianas, do espaço vivido e de uma inquietante familiaridade da cidade". ${ }^{16}$ Mas meu principal interesse aqui é identificar justamente a "disciplina", uma normatização, uma elaboração constituidora e constituinte de um ethos para Laguna. Não é por ser uma cidade urbanamente histórica que deixa de lhe perpassar um discurso que a reconstrói, uma abordagem que tenta parecer a abordagem natural. Pois, como lembra Michel de Certeau, mesmo que na vida urbana proliferem as astúcias, os poderes sem identidade, que escapam e burlam as normatizações, tornando-se impossíveis de gerir, "no discurso, a cidade serve de baliza ou marco totalizador e quase mítico para as estratégias socioeconômicas e políticas". ${ }^{17}$

Com isso quero mostrar que se poderia vislumbrar outras cidades em vez da Laguna que apresento. Poderia-se perambular por ela, perder-se, mesmo que conhecendo sua rede viária, nas fachadas de seu antigo casario, nas esquinas de suas estreitas ruas de calçamento em pedra, ouvindo o canto dos ventos. Compor uma imagem que privilegiasse certos recortes, um olhar espectral, que dimensionasse detalhes escolhidos e reduzisse a importância da totalidade, configurar uma apreciação, ou apropriação, que destoasse da conformidade do conjunto. Como o flâneur de Walter Benjamin na Paris de Baudelaire que se refugia nas massas das ruas da cidade, sentindo-se em casa fora dela, perambulando pelas fachadas das edificações. ${ }^{18}$

A caminhada pela cidade que ora se propõe dá-se diferentemente, vai-se circular pelo discurso que a mostra, seguir os marcos já cristalizados e 
sacralizados, ver a cidade que é visibilizada, olhar os monumentos/documentos das representações oficializadas, instituídas. E sem que se saia delas, porém saindo do "consenso", as conceba de outra maneira: retorcida e deslocada de suas singelezas, questionando seus sentidos, estranhando-as nas suas naturalidades, procurar sua parte que mesmo presente é ocultada, transpor sua aparência tranquilizadora. Não é retirá-las de seu contexto mas perceber nele seus arranjos, buscar os substratos, sua parte constante mas invisível, submersa e mesmo assim de igual material da aparente. Em suma, não reconhecer sua normalidade.

O "amigo radiouvinte" que pela manhã teve anunciada sua identidade cultural na abertura do programa Show do rádio, vai, ao transitar pela cidade, por seu "centro histórico" - que deve ser tomado como substantivo composto, pois inexiste em Laguna outro centro, "histórico" não é adjetivo -, sentí-la confirmada. ${ }^{19} \mathrm{Na}$ pequena área ocupada por seu centro, encontra-se grande número de referências à sua "condição histórica", a começar por sua própria estrutura urbana: pequenas praças e ruas estreitas com calçamento em pedra que moldam quadras disformes.

Nesse espaço encontra-se uma arquitetura que, retratando diferentes épocas, remonta ao século XVIII. Ela é um dos documentos/monumentos usados para afirmar que Laguna é "uma cidade que tem história". ${ }^{20}$ Este documento figura em quase todo o marketing turístico da cidade: seus "antigos casarões", sua "arquitetura riquíssima", seu "casario belo e rico" estão nas publicidades assim como nas publicações de cunho informativo e educacional. "Laguna guarda um passado histórico, com uma rica arquitetura centenária de casarios, ruas estreitas e monumentos que registram o traçado de várias épocas", ${ }^{21}$ diz o encarte turístico da administração municipal do período 93-96. 


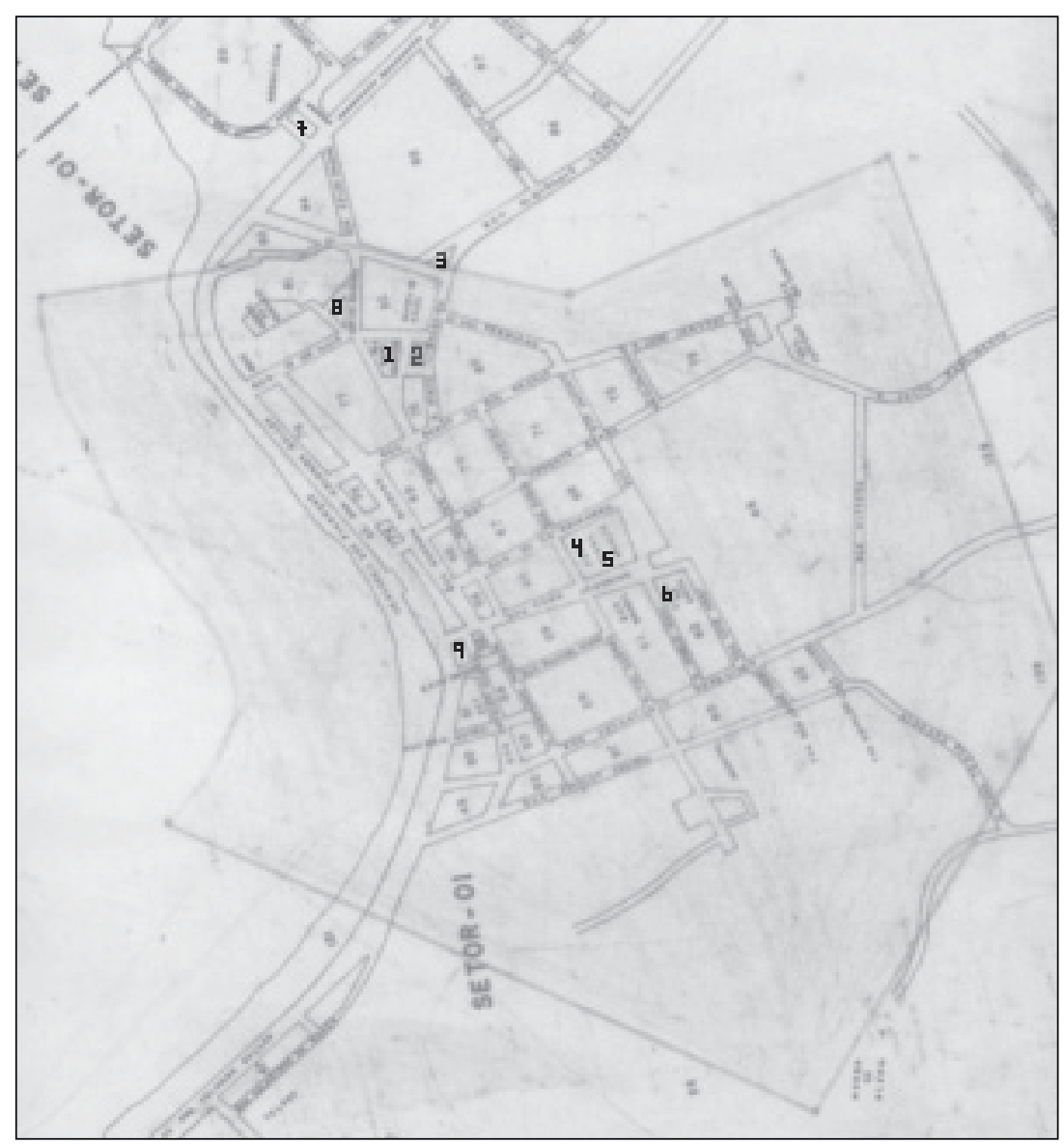

Figura 1: Mapa do centro histórico de Laguna. A região circulada - mais escura - corresponde à área tombada. Fonte: Prefeitura Municipal de Laguna.

Monumentos: 1- Estátua de Anita Garibaldi. 2- Museu Anita Garibaldi. 3Obelisco à República Juliana. 4- Busto de Giuseppe Garibaldi. 5- "Árvore de Anita". 6- Museu "casa de Anita". 7- Marco de Tordesilhas. 8- Herma de Jerônimo Coelho. 9- Estátua de Domingos de Brito Peixoto.

Saindo da paisagem arquitetônica que aparenta certa naturalidade devido a sua formação cumulativa, apesar de sua preservação ser um indício da orquestração que se pretende vislumbrar, passamos aos monumentos. ${ }^{22}$ Não que a arquitetura, assim como o traçado urbano, não se façam monumentos e vice-versa, pois como assinala Jacques Le Goff, "O documento é monumento. Resulta do esforço das sociedades históricas para impor ao futuro - voluntária ou involuntariamente - determinada imagem de si próprias". Pode-se também inverter essa proposição e pensar o monumento como documento, ainda que Le Goff escreva: "os monumentos, [são] herança do passado, e os documentos, escolha do historiador". O autor estava interessado em distinguir a "ciência 
histórica" da "memória coletiva". Estas distinções, mesmo nesse autor, são puramente conceituais e analíticas, já que também a memória é seletiva, pode ser elaborada, direcionada e interage com a construção histórica. Bem por isso, salienta ele que, o que restou de uma determinada época não é apenas fruto das contingências do tempo, mas também de escolhas próprias do mundo social. ${ }^{23}$

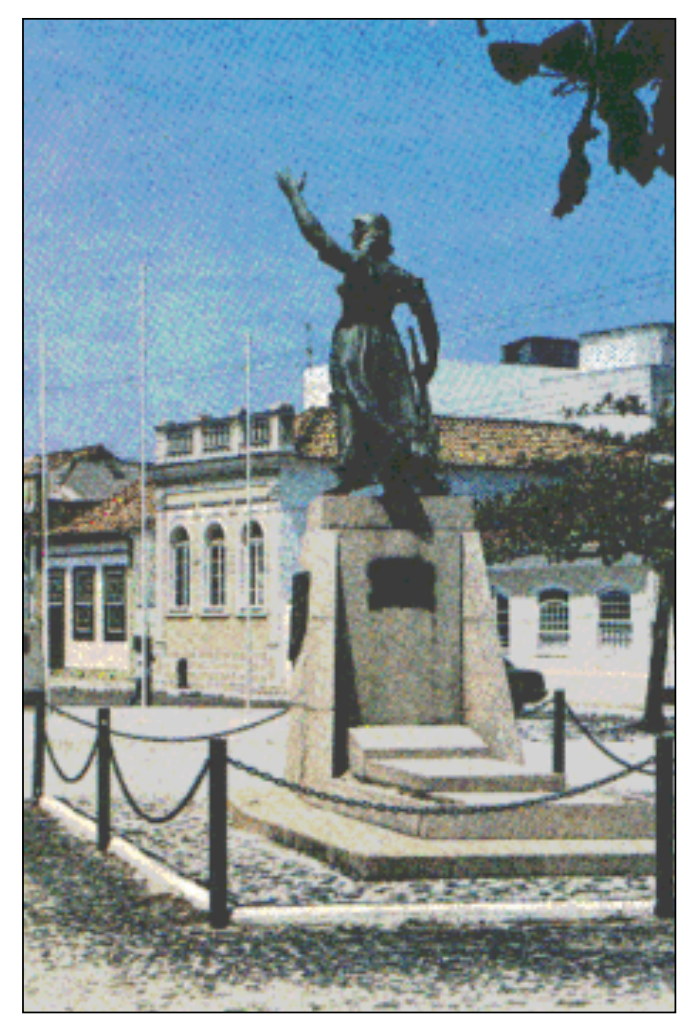

Figura 2: Estátua de Anita. Fonte: Laguna venha viver esta emoção. (folheto turístico da administração municipal de laguna, 1993-96).

Façamos então uma caminhada por esses monumentos e comecemos pelo mais significativo deles, o monumento a Anita Garibaldi(1) ${ }^{24}$, de 1964, situado na praça República Juliana. Mede 2,20 mts de altura, a estátua de Anita em bronze sobre um pedestal em granito rosa, com detalhes de seus "momentos heróicos" também em bronze cravado no pedestal. A imagem de Anita retratada neste monumento, não é outra senão a da "heroína": com a arma em uma das mãos e a outra erguida aos céus, como se estancasse um ato de bravura. Sua imagem não repousa, ela sugere dinamismo, movimentação. Anita aparece com os pés afastados um do outro, num passo largo e rápido, tanto que suas vestes apresentam um relevo que denotam um esvoaçar, flutuando no vento contrário 
ao seu movimento. É sem dúvida a guerreira. Salum Jorge Nacif que esteve à frente do Conselho Municipal de Cultura e iniciou os escritos do que pretendia ser um livro sobre os monumentos e outros elementos da "condição histórica" lagunense, o qual tencionava publicar em comemoração do sesquicentenário da República Juliana cujos festejos era ele presidente da comissão executiva, assim a descreve:

Há uma decisão inapelável naquela face cujos olhos ficam fitando a barra estreita, por onde bordejou, pelejando, o valoroso Seival. É aquela decisão que devotou ao guerreiro ilustre de tantas heróicas lutas pelo mundo livre..$^{25}$

A imagem de Anita pode até direcionar seu olhar à barra como sugerem as palavras de Nacif, mas o que de imediato aparece a quem lhe observa é seu direcionamento ao museu(2), criado em 1956, que também leva seu nome e é um outro forte símbolo da identidade histórica lagunense. O prédio que teve sua primeira parte - bloco mais baixo - construída em 1747 para abrigar o paço municipal, já serviu também de cadeia, de prefeitura e de cenário à proclamação da República Juliana. "Ontem cadeia, prefeitura, palácio da República Juliana, hoje santuário de nossa história", lembra o folder turístico da administração municipal de Saul Ulysséa Baião, 1970-73. ${ }^{26}$ É praticamente inevitável a ligação, confluindo para uma perfeita combinação, Anita ali prostrada, em sua estática aparência dinâmica, indicando para o espaço genuíno dos acontecimentos, lembrando a todos que por ela passam que ali está sacralizado um pedaço da história. Este "santuário" da história lagunense é assim descrito no "guia histórico e turístico" da administração municipal de João Gualberto Pereira, 1983-88:

Instalado no prédio histórico em que foi proclamada a República Juliana, a 29 de julho de 1839, na praça do mesmo nome, o museu Anita Garibaldi, evoca três séculos de arte e história, com valiosíssimas peças, que rememoram a heroína lagunense (Anita Garibaldi). ${ }^{27}$

Anita, assim como a República Juliana, não recebe somente estas homenagens. Existem outros marcos pela cidade reportando aos personagens e acontecimentos da República Catarinense. Na praça Pinto Bandeira existe um obelisco(3) em granito branco inaugurado em 29 de julho de 1939, em comemoração ao centenário da República Catarinense. Nas placas lêm-se as seguintes inscrições "A heroína de dois mundos - sua terra natal”, "Aos heróis Lagunenses da epopéia de 1839". ${ }^{28}$ 
No jardim Calheiro da Graça em frente à igreja matriz encontra-se um monumento comemorativo ao centenário da morte de Giuseppe Garibaldi (4), inaugurado em 02 de junho de 1982 e diante deste, está plantada a "Árvore de Anita" (5) que, segundo uma placa ali colocada, nasceu da quilha do Seival, um dos lanchões usados por Garibaldi nas batalhas dos Farrapos em Santa Catarina. Na esquina do mesmo jardim, ao lado da matriz Santo Antônio dos Anjos, encontra-se a "casa de Anita" (6), um museu dedicado inteiramente à "heroína lagunense". A edificação foi restaurada e transformada em "relicário histórico" no ano de 76, como parte das comemorações do tricentenário de Laguna.

$\mathrm{Na}$ avenida Perimetral próximo à estação rodoviária encontra-se o monumento de Tordesilhas (7) cuja inauguração em 07 de junho de 1975, também fazia parte das comemorações do tricentenário de criação de Laguna (1676-1976). O monumento mostra o mundo dividido pelo Tratado de Tordesilhas, acordo, segundo a história oficial, firmado entre Portugal e Espanha em 1494 que estabelecia um meridiano dividindo o mundo a ser "descoberto". No Brasil esta linha imaginária passava, ao norte, em Belém no Estado do Pará e, ao sul, em Laguna. Entre o monumento de Tordesilhas e a estátua de Anita Garibaldi acha-se, no largo do rosário, o monumento a Jeronimo Francisco Coelho (8), inaugurado em 28 de julho de 1981 como parte da comemoração dos 305 anos de Laguna. Jerônimo Coelho, "fundador" da imprensa catarinense e político de prestígio na época do império brasileiro, é um dos "filhos ilustres" que, de acordo com as publicações do poder público local, merecem participar da memória do município. Ele é, dentro deste tipo de história, um personagem ideal, um "vulto lagunense" que engrandece o passado da cidade, "o Conselheiro Jerônimo Francisco Coelho é motivo de orgulho para o povo lagunense", ${ }^{29}$ lê-se em um "guia histórico e turístico" da prefeitura municipal da gestão 1983-88.

Finalizando este giro desordenado pelos maiores monumentos do centro de Laguna, chega-se à estátua de Domingos de Brito Peixoto(9), criador da cidade, inaugurada em janeiro de 1983. A colonização iniciada em Laguna por Brito Peixoto é um fato que não esgota sua importância em si mesmo. Seu significado e dimensão extrapolam ao próprio ato. As narrativas deste acontecimento mostram que o bandeirante ao "fundar" Laguna em sua aventura pelo sul, também insere sua relevância na história do Brasil. A importância desta "fundação" assim é relatada no guia Laguna: a natureza e o passado sempre presentes:

Uma das razões determinantes da fundação de Laguna foi para que a Coroa Portuguesa tivesse, no extremo de sua Colônia, um "posto avançado" de seu então mal definido 
domínio. Seria, como foi, um ponto de apoio ao povoamento do Rio Grande do Sul e às lutas hispanolusitanas na Bacia Platina. ${ }^{30}$

Além dos monumentos aqui mostrados, nessa caminhada pela cidade visibilizada, existem outros que optei por não utilizar, seja por sua insignificância diante dos apresentados, seja por não se configurarem relevantes ao interesse dessa pesquisa ou, ainda, por não acrescentarem nada mais que os exibidos já não demonstrassem. Mesmo não apresentando os demais monumentos, assim como outros documentos/monumentos usados para afirmar sua história, que na atualidade são redirecionados por uma prática que faz a cidade figurar como "pólo turístico", o material apresentado é suficiente para vislumbrar como Laguna é pontuada de marcos simbólicos, direcionados a adquirir uma significação homogênia, única, que lhe garantem a imagem de "cidade monumento", patrimônio histórico nacional, cidade histórica. Estes monumentos demonstram como na organização do espaço dão-se estratégias de controle, de manipulação da memória e de criação de imaginários.

Como os demais marcos, os monumentos, visam produzir na vida cotidiana a crença necessária à afirmação do discurso histórico aos lagunenses. O indivíduo desta sociedade não vai, na sua cotidianeidade, investigar a veracidade destas relações. $\mathrm{Na}$ existência cotidiana, as ações são norteadas pela confiança e pela fé. ${ }^{31}$ Esta crença pretende modelar e nortear as atitudes dos agentes sociais na medida em que o material simbólico que a compõe e a sustenta se estabelece como comunicação legítima de uma realidade evidente e única. "O real contado dita interminavelmente aquilo que se deve crer e aquilo que se deve fazer". ${ }^{32}$ Assim, com toda a multiplicidade de informação por várias mídias, seja no Show do rádio, nos museus, nas estátuas, nos folhetos publicitários, enfim por toda a rede simbólica e discurssiva que dá esteio a esta identidade construída, possivelmente, os lagunenses terão dificuldade em recusar estas construções, colocando-as em suspenso, tomando-as enquanto uma possibilidade. Ao contrário, tudo se fecha ao seu redor para a aceitação desta imagem da cidade, que lhe é dada a ser compartilhada e assimilada, apresentada de tal modo que os lagunenses devam se sentir parte integrante. Como se pode encontrar em uma publicação da prefeitura municipal, destinada à utilização nas escolas e divulgação junto à comunidade e visitantes, a qual incide sobre o dever dos lagunenses em prestigiar e preservar esta tradição para cidade; que se torna o potencial turístico, fazendo afluir para Laguna visitantes em busca "...de uma identidade que perderam nas grandes cidades ao se despojarem de quase todo o seu passado, testemunha de seu evoluir." Então, alerta esta publicação: 
Os lagunenses são hoje herdeiros de um documento histórico vivo, retratado nas páginas do tempo, fruto das lutas e conquistas deste povo. Preservar-se como um Monumento Nacional constitui uma responsabilidade histórica de Laguna para com o Brasil, [...]..$^{33}$

Os documentos/monumentos são uma forma de impingir certa ordenação ao mundo social; é a formação de uma tradição que Hannah Arendt chama de "fio condutor", a presentificação do passado, a atualização da vida social, que vai compor a compreensão do mundo de cada nova geração. ${ }^{34}$ Os marcos e símbolos atuam no mundo social dando-lhe organização, normatividade, podese pensar que eles agem em relação ao caos, como é impossível o domínio sobre a temporalidade e ordenação próprias do mundo - se é que existe alguma - no mundo social criam-se marcos, símbolos e mitos que dão certa constância às coisas. Por isso a importância do controle sobre as representações e sobre o material simbólico, que atuam sobre a memória social. Pois a incerteza e a indeterminação que acompanham os símbolos e os objetos das representações permitem a variação dos sentidos dados a eles, ou seja, como o significante não possui um sentido absoluto em si, possibilita um leque de significados. ${ }^{35}$

Deste modo, a "condição histórica" lagunense, não pode ser encarada como a transparência da realidade, o real em sua autenticidade, mas uma imagem que é a própria realidade com a qual se está lidando e convivendo. A história lagunense, construída enquanto tradição e simbolizada nestes documentos/monumentos, é capaz de reunir o que Clifford Geertz denomina de "ethos" e "visão de mundo". Os símbolos desta identidade foram sacralizados e mitificados. Compõem um arcabouço de valores para Laguna que pretende orientar as ações dos indivíduos na vida cotidiana, organizar suas condutas e dar significados às suas experiências. Os valores contidos nessa tradição tornamse o sentido natural das coisas; a ordenação criada com a tradição combina em perfeita afinidade, e não poderia ser diferente, já que se trata de uma única construção, com uma ordem geral, com a apreciação da realidade reconhecida como evidente. Na medida que esta tradição é mitificada e sacralizada, não permite pensar na possibilidade, na escolha, na opção. Fazendo-se crer objetiva, única possível, condição natural do trilhar dos acontecimentos no tempo. "Nos rituais sagrados e nos mitos, os valores são retratados não como preferências subjetivas, mas como condições de vida impostas, implícitas num mundo com uma estrutura particular". ${ }^{36}$ Estas "condições" determinadas pelas particularidades que lembra Geertz figuram atualmente na tradição de cidade histórica inventada para Laguna como definidora incontestável de sua "vocação" turística: 
A condição histórica de Laguna, a permanência de padrões de arquitetura colonial e, sobretudo, a combinação entre a posição geográfica - próxima da BR-101, e a metrópole porto-alegrense - e a morfologia litorânea lhe conferem nítida vocação de centro turístico. ${ }^{37}$

A cristalização dessa "vocação", principalmente no que tange à sua "condição histórica", passa também pela divulgação em folhetos educativos que mostram os seus "três séculos de Brasilidade". Neles são encontrados os "filhos ilustres", os "dados históricos", grandes feitos e grandes momentos, que devem ser lembrados, pois afirmam Laguna como "pólo cultural e histórico de Santa Catarina". ${ }^{38}$ Bronislaw Baczko lembra que o grau de influência dos imaginários sobre os agentes sociais depende, em muito, de sua difusão, por isso a importância dada aos meios desta propagação. O sucesso de uma identidade construída é alcançado proporcionalmente à intensidade de sua divulgação. É isto que faz Laguna ser pontuada de monumentos e inflada de publicações que afirmam ser ela uma cidade que "tem uma história riquíssima e feitos inacreditáveis. Um patrimônio histórico de extraordinário valor cultural" ${ }^{39}$

Nesses folhetos e nos folders não aparecem apenas as narrativas de seus "grandes" momentos, mas também o material referente a estes momentos narrados. Não se apresenta somente uma história da República Juliana, mostram-se também seus monumentos e museus. "Sendo o berço da República Catarinense, proclamada em 29 de julho de 1839, a Casa de Anita, juntamente com sua estátua, registram um período heróico de nossa história" diz o folheto turístico da administração 93-96. ${ }^{40}$

O que insinua estar colocado na construção e indicação do referente são as estratégias de fazer crer, "o 'real' é aquilo que, em cada lugar, a referência a um outro faz acreditar", ${ }^{41}$ manter a credulitude, pois os monumentos/ documentos desta imagem histórica podem perder significado na medida em que só vive o que é lembrado e só é lembrado o que tem sentido. O referente é uma forma de não esvaziar de confiança e fé o material simbólico, não permitindo o deslocamento da crença para objetos fora da tradição. Deve-se reconhecer que a vivência e as experiências do presente podem possibilitar a elasticidade ou distorção dos significados, por isso a utilização desses dispositivos de apreensão. Pierre Bourdieu afirma que na imposição de uma nova realidade social, "as mais típicas dessas estratégias de construção são as que visam reconstruir retrospectivamente um passado ajustado às necessidades do presente - [...] - ou construir o futuro, por meio de uma predição criadora, destinada a delimitar o sentido, sempre aberto, do presente". ${ }^{42}$ Por isso a história constante dos folhetos e folders convergem para a imagem de "pólo turístico" 
do mesmo modo que o investimento nessa "vocação" da cidade é apresentado como a certeza de prosperidade futura.

O homem moderno parece viver numa constante luta entre o passado e o futuro, fazer seu amanhã sugere implicar constantes rupturas com a tradição, mesmo que estas rupturas funcionem no interior desta tradição, fazendo com que alguns de seus elementos permaneçam. Mas, em se tratando da identidade histórica lagunense, que figura atualmente como constitutiva de seu potencial turístico, que também é a proposta de desenvolvimento futuro, tudo leva a crer que o campo de batalha se esvazia, estas duas forças não se confrontam, se coligam e se confirmam, para além do "fio condutor" das novas gerações. Essa tradição para Laguna é também seu produto e investimento; é seu futuro, não se trata de romper com o passado e, sim, afirmá-lo. A tradição é coisificada, o passado é materializado, objetivado. Mora aí a dificuldade de sair do "consenso", romper com o passado, negar a "condição histórica", transpor esta realidade instituída. Fazê-lo é desenhar a morte do futuro. E não é isso justamente que sustenta todo discurso totalizador, a projeção que supera os riscos, a certeza anunciada por ele de um futuro melhor e garantido?

A tradição se converte em proposta de futuro já que ela é o material para produção de seu desenvolvimento, o que faz haver poucas diferenças entre um folder publicitário e um folheto educativo, sendo o segundo mais extenso, com textos mais longos e explicativos e o primeiro ocupando-se mais de material visual. Porém, no que se refere a seus conteúdos não há propriamente divergência. São sempre seus monumentos, sua arquitetura, seus vultos, sua importância histórica, colocados num misto de reverência mítica com mercadoria, atração turística. A combinação entre sagrado e profano é muito bem dosada, não se apresenta como contradição, um civismo em respeito à tradição que é a mesma imagem colocada à venda. É a tradição na vitrine, exposta. O passado que organiza as ações do presente, ou seja, seu ethos, a "condição histórica", é a proposta de futuro, de desenvolvimento, assim apagam-se as contradições. Uma amostra desta estreita relação é a publicação em jornais locais de material idêntico ao encontrado em folders turísticos.

"Laguna possui inúmeras obras que nos trazem à lembrança um passado cheio de heroísmo e dedicação", ${ }^{43}$ diz um folder turístico da prefeitura municipal, enquanto o folheto Caderno de Laguna $\mathrm{n}^{\circ}$ 1, produzido principalmente para utilização didática nas escolas do município, traz o roteiro de um passeio por Laguna em que muitos pontos atentam para sua história. Essa imbricação entre marketing turístico e educação da população serve de convencimento ao turista que a visita, e lógico, de dispositivo do turismo, pois não será difícil encontrar um lagunense que dê informações do que a cidade pode proporcionar nesta área. Entretanto, este entrelaçamento tem ainda o efeito de confirmar aquilo que o "amigo radiouvinte" recebe por toda a rede que lhe convence da sua 
identidade cultural. É mais um fio desta tessitura, não só pelo fato de ver na cidade o turista que se interessa e comenta sobre sua tradição, também pela circulação deste material publicitário entre os próprios lagunenses. O que temos aqui são mecanismos de convencimento, um tipo de informação e educação não formalizado, uma espécie de coerção que tenta modelar a recepção, as apropriações sobre a qual os lagunenses constroem suas visões de mundo, conclamando-os a agir de acordo com a tradição criada. Unificando, diluindo o indivíduo num conjunto valorativo comum, quando informa comprova uma realidade como evidente e legitima um poder, certamente o de quem a criou e nela tem interesses.

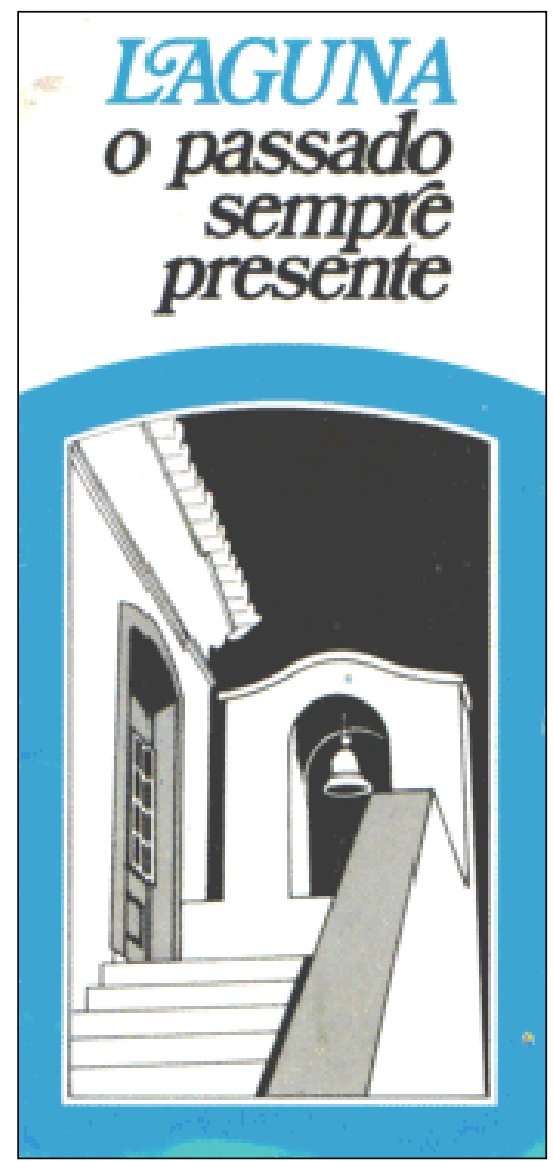

Figura 3: "Folder" da Pref. Municipal de Laguna.

Esses materiais, assim como o restante, estão sempre a afirmar que Laguna é uma "cidade monumento" com "atrações turísticas por todos os lados", mesmo que em um ou outro varie um pouco a importância dada à sua história, dando mais ênfase às praias e às belezas naturais, por exemplo, o que sobressai é a intenção de convencer que Laguna tem "o passado sempre 
presente". Esta afirmação, presente em vários folders, faz-se síntese da discussão. Dizer que o passado é sempre presente é afirmar a não-ruptura com a tradição, é negar a mudança, não só agora, mas para todos os tempos, é predizer seu futuro. A enunciação desta afirmação estabelece uma Laguna infinitamente marcada por sua "condição histórica"; se o passado é sempre presente ele ultrapassa qualquer demarcação temporal, ele é presente nele, hoje e eternamente. Mais que isso, "sempre" é uma afirmação enunciativa que a tudo abarca. Assim, é impossível sair dela, apagá-la, vencê-la ou matá-la, ela é inevitável e mesmo que haja divergências, contestações e resistências, ela permanecerá, "sempre", eternamente viva, à vista.

Se Laguna tem "o passado sempre presente" como anuncia o poder público local, há de imediato um problema na existência dessa afirmação. Se o passado está no presente, se ele se faz presente na vivência do presente, falta tempo e espaço, para existência de uma dessas duas temporalidades, ou, pode haver a coexistência de ambas, só que para isso, uma delas tem que ceder espaço e tempo à outra. Esta questão, a própria enunciação responde. Se é o passado que se presentifica, parece estar bastante definido o que está sendo desqualificado, principalmente se levarmos em conta que, para Laguna do discurso da cidade histórica o passado se travesti em proposta de futuro.

Mergulhar nas profundidades do passado, este parece ser o ideal discursado para modelar a conduta dos lagunenses. Caminhar de costas para o futuro, não negá-lo, mas seguir adiante olhando para trás, reverenciando o passado, inclinando-se não sobre, mas diante dele, como um súdito que se curva perante sua majestade. Esta discursividade fascinada pelo passado pode ser encontrada até no hino da cidade, oficializado pela lei municipal $\mathrm{n}^{\circ} 32$ de 1975, sancionada pelo prefeito Francisco de Assis Soares, cuja letra fala da glória da história lagunense e do zelo do povo para com a cidade.

\author{
Minha Laguna \\ Cantarei tua história \\ E os feitos de tua glória que ofertaste ao Brasil \\ E falarei... \\ Das belezas sem par \\ Deste céu, deste mar \\ Destas praias sem fim \\ Minha Laguna... \\ Falarei do teu povo \\ Que adora o que é novo \\ Sem matar o passado... ${ }^{44}$
}

O enunciado do hino bem que poderia figurar nas páginas dos folhetos informativos do município ou nos folders turísticos. O sentido de suas palavras 
não difere do apresentado no material publicitário da cidade. A Laguna do hino, como a do marketing turístico, possui uma importância histórica associada às belezas naturais. Além disso, tem um povo que se orgulha de seu passado, que não o deixa morrer, ainda que adore o novo. No hino está sintetizada essa construção identitária para Laguna, que faz de seu passado o manancial de seu futuro. É certo que o hino não traz alusões explícitas ao turismo, porém basta contrastar o material publicitário ao enunciado do hino, que esta ligação se torna extremamente evidente. Mesmo porque, não é necessário que se façam relações tão expostas, uma vez que é a própria tradição o elemento colocado na vitrine, as intenções dessa criação identitária tendem a ficar invisíveis e as relações buscadas para interiorizar a legitimação desta proposta de futuro dão-se de formas bastante sutis. É mais uma forma de educação, de modular e moldar uma apreciação sobre a sociedade lagunense, de tentar normatizar as representações do mundo social. Assim, por exemplo, não foi difícil encontrar a publicação da letra deste hino em um jornal atual da cidade. ${ }^{45}$

Esta não é uma situação ímpar na imprensa lagunense. Vêem-se nos jornais várias referências a afirmar a grandiosidade da história de Laguna, não somente no conteúdo que se publica, mas também na forma como esse conteúdo é inserido nos periódicos, como a coluna Retalhos da cidade antiga assinada por João Carlos Silveira no jornal $O$ Correio. Esta coluna fala do passado da cidade não somente através de textos atuais, mas de apresentação de artigos de antigos jornais e fragmentos de publicações acerca do passado lagunense que lhes sucedem na página.

O material historiográfico, do qual os jornais se utilizam, e as demais representações de sua história criam uma Laguna com um passado glorioso. Porém, este passado não é bem contextualizado, pois da maneira apresentada, o passado aparenta, no senso comum, ser um bloco monolítico, uma época áurea onde tudo dava certo. Sua história, deste modo, sugere a compreensão de um mundo em um tempo de vitórias. Este tempo condensa a quase totalidade dos seus mais de trezentos anos. Grosso modo, o que se chama de passado glorioso engloba momentos distintos, fragmentos de diversas épocas em uma junção desconcertante, mas convencedora. No passado glorioso enfatiza-se, entre outras coisas, um grande território nos seus primeiros tempos que ia de Porto Belo ao Rio Grande do Sul, os feitos heróicos da República Juliana em 1839 e o desenvolvimento comercial na segunda metade do século XIX. "Laguna era uma cidade resplandecente no sul de Santa Catarina. CidadeMãe, pólo irradiador da cultura, arte e economia. Seu território era bem mais abrangente..." ${ }^{46}$ diz um artigo da edição número 14 de 1995 do jornal $O$ Correio.

Da forma como é apresentada, essa história forja a idealização de um passado de vitórias, como se nas relações de existência no desenrolar do 
vivido deste passado não se dessem disputas e conflitos. A história lagunense é então construída como um passado somente de afirmação. Mesmo as batalhas vencidas são revestidas de uma glória épica, de um ideal que virá a ser afirmado. Aquilo que possa demonstrar fracasso e retrocesso, o que poderia ser abordado como uma história de possíveis não realizados, de projetos vencidos, de derrotas sofridas, não se encontra em relatos oficiais.

A época áurea, em seu arranjo monolítico, é divulgada no conjunto de elementos que formam a teia de representações simbólicas e discursivas que estão sempre confirmando Laguna como "berço da cultura e da história de Santa Catarina". ${ }^{47}$ Tanto se fazem concretas essas ligações que a indicação encontrada na obra organizada por Dall' Alba, denominando Laguna como "célula máter da brasilidade do sul", ${ }^{48}$ foi reafirmada em entrevista com lagunenses: "Laguna sempre foi a célula máter do sul", ${ }^{49}$ relatou a secretária de educação municipal, Amélia Baungarten Baião, enquanto o assessor de imprensa da prefeitura, João Manoel Vicente, proferiu que "Laguna era a cidade mãe do sul". ${ }^{50}$

Estes exemplos servem para demonstrar a afinidade entre a construção historiográfica e a memória social lagunense, o que leva a crer nos investimentos sobre a construção dessa memória. Pois, mesmo reconhecendo as amenizações próprias do recordar, o efeito de apagar do passado os maus momentos, as dificuldades e idilizá-los, é preciso perceber as articulações e montagens que lhe perpassam. A memória, enquanto experiência vivida e transmitida socialmente, tende a adocicar o sabor dos acontecimentos passados. A distância e a consciência do já ocorrido eliminam o perigo do jogo da vida do momento vivido, fazendo com que a memória constantemente atribua ao passado harmonia, passividade e felicidade. Para além das tintas coloridas com que a memória tinge o passado há as maquinações, as fabricações, que buscam normatizar visões, construir estruturas que definam apropriações. Se a memória é sempre a recordação de alguém sobre um acontecimento e não o acontecimento, ${ }^{51}$ esta recordação pode sofrer conduções e direcionamentos, principalmente quando se faz coletivamente no mundo social.

Em estudo sobre os lugares de memória, Pierre Nora diz que as sociedades modernas não vivem sobre o seu domínio. O que chamamos de memória é, ao contrário, a sua negação, a história. Para esse autor a história é a morte da memória e os espaços onde se tenta aprisionar a memória, os símbolos que tentam lhe garantir o sentido, são, na verdade, marcos da sua inexistência, pois se vivêssemos realmente a memória não necessitaríamos de sinais para lembrá-la, rememorá-la. "À medida em que desaparece a memória tradicional [escreve Nora], nós nos sentimos obrigados a acumular religiosamente vestígios, testemunhos, documentos, imagens, discursos, sinais visíveis do que foi, como se esse dossiê, cada vez mais prolífero devesse se tornar prova em não se sabe que tribunal da história". ${ }^{52}$ 
Concordando com as colocações de Nora, pode-se ver na Laguna, pontuada por monumentos, placas, museus, em toda a história materializada, a elaboração de uma memória coletiva para a cidade, que se constrói na medida em que informa sobre sua "condição histórica". Pois, se aquilo que se faz memorizar realmente se constituísse em uma existência presente, não necessitaria ser lembrado, seria espontaneamente vivido. ${ }^{53}$ Ao contrário são nas representações simbólicas que repousam esta construção de identidade para Laguna. Trata-se então de um discurso autorizado, um discurso que utiliza de toda esta teia de material simbólico como aparato e instrumento de poder que lhe dá suporte, que lhe confere a capacidade de se fazer escutar e que fundamenta sua "competência" num interdiscurso ; já que os agentes sociais não procuram "somente ser compreendidos, mas também obedecidos, acreditados, respeitados, reconhecidos. Daí a definição completa da competência como direito à palavra, isto é, à linguagem legítima como linguagem autorizada, como linguagem de autoridade. A competência implica o poder de impor a recepção". ${ }^{54}$

O "discurso competente", assim, tenta regular as apropriações, as visões de mundo dos sujeitos sociais. É um discurso instituído, normativo e preceitual, procura, ainda que sutilmente, impor proibições a multiplicidade discursiva. "Em toda a sociedade a produção do discurso é ao mesmo tempo controlada, selecionada, organizada e redistribuída por certo número de procedimentos que tem por função conjurar seus poderes e perigos, dominar seu acontecimento aleatório, esquivar sua pesada e temível materialidade". ${ }^{55}$ Por isso, não é permitido a qualquer indivíduo a condição de dizer qualquer coisa em qualquer lugar a qualquer hora, é um jogo de três interdições: "Tabu do objeto, ritual da circunstância, direito privilegiado ou exclusivo do sujeito que fala". ${ }^{56}$ Contudo, ainda, o "discurso competente" se estabelece no ponto nodal das relações dos agentes sociais, ele passa a mediar as interações dos indivíduos com seu mundo, com seu corpo, norteia suas experiências, enseja práticas e confere compreensão a sujeitos e coisas, dando aos indivíduos a aparência de normalidade intrínseca, de uma evidente naturalidade própria da vida.

Atualmente a tradição de cidade histórica, sustentada em toda a rede simbólica e discursiva que lhe faz presente e visível, cobre a cidade de Laguna com uma imagem de "pólo turístico". Seu passado é material de extrema importância nesse projeto para cidade, mesmo suas autoridades não querendo reconhecer o atributo de mercadoria dado a sua história nesta conjuntura, pois a história oficializada está ligada ao respeito à tradição, com uma forte crença no resgate do passado como realmente foi, mas acabam por reconhecer que a "condição histórica" lagunense, enquanto patrimônio cultural, pode ser um "produto de interesse turístico". Isto é, a proposta de futuro utilizando esta 
própria tradição. Nesse sentido, é em um dos folders turísticos da prefeitura que encontro um bom sentido para essa construção de identidade:

Y lo más importante: Laguna tiene una infraestrutura montada para atender a los turístas. Sus hoteles, como el Laguna Tourist, el Itapirubá, Ravena, son de los mejores de Santa Catarina. ${ }^{57}$

Isso deve ser realmente "o mais importante". Não é, portanto, por acaso que os empreendimentos hoteleiros citados possuem também grandes loteamentos imobiliários, concentrando grande quantidade de terras na faixa litorânea, com parte delas ainda hoje intocadas. Convencer os lagunenses de seu passado histórico é hoje convencê-los de fazer parte de um projeto turístico, colocado como proposta de futuro para cidade, senão única, pelo mesmos, diz-se dela a exeqüível, a potencialmente viável. Talvez seja por isso, pelo fluxo turístico, que a abertura do programa Show do rádio de bom dia inicialmente para quem vai viajar, para depois cumprimentar os que vão trabalhar ou estudar. Porém há outros que viajam os que verdadeiramente partem, os que não encontram perspectiva de sobrevivência em uma cidade na qual seus poderosos desenvolvem um projeto para longo prazo que, por hora, parece ter mais interesse no convencimento desta "vocação" do que promover as condições de infra-estrutura necessária a sua concreta eficiência.

\section{NOTAS}

1 Este artigo é uma versão compacta do primeiro capítulo de minha dissertação de mestrado. BITENCOURT, João Batista. Clio positivada: a artesania da cidade histórica de Laguna. Florianópolis: Dissertação (Mestrado em História) UFSC, 1997.

2 Abertura do programa Show do rádio, transmitido diariamente pela rádio Garibaldi de Laguna.

3 João Manoel Vicente (radialista e assessor de imprensa da Pref. Municipal de Laguna). Entrevista concedida a João Batista Bitencourt. Laguna, 07 maio 1996.

${ }^{4}$ CHARTIER, Roger. A história cultural: entre práticas e representações. Lisboa: Difel, 1990. p. 17.

5 Segundo Dominique Maingueneau toda formação discursiva, como também toda formulação particular são perpassadas por um interdiscurso que lhes são anterior e lhes intervêm. "Assim, toda formulação estaria colocada, de alguma forma, na intersecção de dois eixos: o 'vertical', do pré-constuído, do domínio de memória e o 'horizontal', da linearidade do discurso, que oculta o primeiro eixo, já que o sujeito enunciador é produzido como se interiorizasse de forma ilusória o pré-construído que sua formulação discursiva impõe.”(p. 115) Contudo, esta é uma relação de interação constante, continuamente mutável, pois ao passo que uma formação discursiva compõe-se dentro do interdiscurso tomando elementos já construídos ela os reconfigura, 
pode redefini-los ou mesmo apagá-los, incorporando seus próprios elementos. "Como se vê, contrariamente às representações espontâneas dos sujeitos, a formação discursiva aparece como o lugar de um trabalho no interdiscurso; ela é um domínio 'inconsistente', aberto e instável, e não a projeção, a expressão estabilizada da 'visão de mundo' de um grupo social.”'(p. 113). MAINGUENEAU, Dominique. Do discurso ao interdiscurso. In: Novas tendências em análise do discurso. 2 ed. Campinas: Pontes/UNICAMP, 1993. p. 111-126.

${ }^{6}$ CHAUI, Marilena. Cultura e democracia: $\mathrm{O}$ discurso competente e outras falas. $6^{\mathrm{a}}$ ed. São Paulo: Cortez, 1993. p 42.

7 FOUCAULT, Michel. A arqueologia do saber. 4 ed. Rio de Janeiro: Forense Universitária, 1995. p. 24.

${ }^{8}$ Para uma compreensão da utilização da imagem histórica de Laguna em outros contextos, consultar: BITENCOURT, João Batista. Clio positivada: a artesania da cidade histórica de Laguna. Florianópolis: Dissertação (Mestrado em História) UFSC, 1997.

9 FOUCAULT, Michel. A arqueologia do saber. 4 ed. Rio de Janeiro: Forense Universitária, 1995. p. 54.

${ }^{10}$ Utilizo da expressão "condição histórica", colhida no material de divulgação da cidade produzido pelo poder público, para sintetizar o manancial de referências pretéritas ocupado nessa construção de identidade.

${ }^{11}$ Stella Bresciani ao comentar o pensamento de Camillo Sitte, faz esta distinção. Segundo ela: "Os adeptos da solução técnica moderna de cunho universalista se opõem aos que defendem a dimensão cultural e histórica das cidades" (p. 7). BRESCIANI, Stella. Apresentação. In: (org.) Imagens da cidade: Séculos XIX e XX. São Paulo: Marco Zero/ANPUH-SP/ FAPESP, 1994. p. 7-11.

${ }^{12}$ BACZKO, Bronislaw. Imaginação social. In: Enciclopédia Einaudi. Lisboa: Imprensa nacional-Casa da Moeda. v. 5. 1995. p. 313.

${ }^{13}$ Sobre a legislação que dispõe sobre os bens tombados pelo patrimônio municipal, ver: LAGUNA, Prefeitura Municipal. Lei no 5 de 26 nov. 1975, decreto $\mathrm{n}^{\circ} 27$ de 22 out. 1976, decreto 17 de 2 out. 1978, decreto 26 de 20 ago. 1981 e decreto $\mathrm{n}^{\circ} 28$ de 27 dez. 1982.

${ }^{14}$ ECOS do primeiro centenário da comarca da Laguna. O Albor. Laguna, 21 abr. 1956. p. 1.

${ }^{15}$ SOUZA, Alcídio Mafra de. Guia dos bens tombados Santa Catarina. Rio de Janeiro: Expressão e Cultura/FCC, 1992. p. 103.

${ }^{16}$ CERTEAU, Michel de. A invenção do cotidiano. Petrópolis: Vozes, 1994. p. 175.

${ }^{17}$ Ibid. p. 174.

${ }^{18}$ BENJAMIN, Walter. A Paris do segundo império em Baudelaire. In: KOTHE, Flávio R.(org.). Walter Benjamin. São Paulo: Ática, 1985. p. 44 -122.

${ }^{19}$ Devo ressaltar, no entanto, que o Mar Grosso, um bairro balneário, tem mostrado um bom índice de crescimento urbano nos últimos anos, com um grande número de edificações verticalizadas. Porém seu movimento é sazonal, com grande efervescência na temporada de verão, ficando os demais meses do ano com uma população muito reduzida. Apesar de seu grande desenvolvimento recente não o configuro como um centro, mesmo porque as atividades administrativas, comerciais e de serviços permanecem centradas na parte "histórica" de Laguna. 
${ }^{20}$ PREFEITURA MUNICIPAL DE LAGUNA. Laguna, venha viver esta emoção. (folheto turístico da administração 93-96).

${ }^{21}$ PREFEITURA MUNICIPAL DE LAGUNA. Laguna, venha viver esta emoção. (folheto turístico da administração 93-96).

${ }^{22} \mathrm{O}$ que chamo aqui de monumentos são estátuas, obeliscos e outros do gênero que são no senso comum chamados como tal. Optei por nomeá-los monumentos porque assim estão nas publicações oficiais da cidade. Nesta mesma classificação aparecerão os museus.

23 "De fato, [lembra Le Goff] o que sobrevive não é o conjunto daquilo que existiu no passado, mas uma escolha efetuada quer pelas forças que operam no desenvolvimento temporal do mundo e da humanidade, quer pelos que se dedicam à ciência do passado e do tempo que passa, os historiadores" (p. 535). LE GOFF, Jacques, História e Memória. 3 ed. Campinas: Editora da UNICAMP, 1994. As citações deste parágrafo encontram-se respectivamente nas páginas 548 e 535 .

${ }^{24} \mathrm{O}$ número que acompanha cada monumento é respectivamente o número que aponta sua localização no mapa acima.

${ }^{25}$ NACIF, Salum Jorge. Os monumentos da Laguna e outros apontamentos para a história da terra juliana. Laguna. 1989. (mimeo - incompleto e inédito). Salum J. Nacif respondeu pelo Conselho Municipal de Cultura durante as administrações dos prefeitos Mário José Remor, 1977-83, e João Gualberto Pereira, 1983-88. Estas gestões tiveram uma continuidade administrativa, João G. Pereira foi também vice do prefeito Mário J. Remor.

${ }^{26}$ PREFEITURA MUNICIPAL DE LAGUNA. Laguna espera por você. (folder turístico da administração 1970-73).

${ }^{27}$ PREFEITURA MUNICIPAL DE LAGUNA. Laguna: a natureza e o passado sempre presentes. (guia histórico e turístico da administração 1983-88). p.12.

${ }^{28}$ Este obelisco foi primeiramente instalado na praça República Juliana e transferido para o local atual em 1964, quando naquela praça foi inaugurada a estátua de Anita Garibaldi. Posteriormente, na administração do prefeito João Gualberto Pereira, 1987, foi inserida neste monumento uma placa em homenagem aos voluntários da Guerra do Paraguai.

${ }^{29}$ PREFEITURA MUNICIPAL DE LAGUNA. Laguna: a natureza e o passado sempre presentes. (guia histórico e turístico da administração 1983-88). p. 05.

${ }^{30}$ PREFEITURA MUNICIPAL DE LAGUNA. Laguna: a natureza e o passado sempre presentes. (guia histórico e turístico da administração 1983-88). p. 03.

${ }^{31}$ Como lembra Agnes Heller "Ao astrônomo, não basta ter fé em que a Terra gira em redor do Sol; mas, na vida cotidiana, essa fé é plenamente suficiente. Não basta ao médico acreditar na ação terapêutica de um remédio, mas essa fé é suficiente para o enfermo". HELLER, Agnes. O cotidiano e a história. $4^{\mathrm{a}}$ ed. São Paulo: Paz e Terra, 1992. p 33.

${ }^{32}$ CERTEAU, Michel de. A invenção do cotidiano. Petrópolis: Vozes, 1994. p. 287. Este autor tratando da instituição do real na sociedade da informação, faz uma descrição do mundo social saturado pela mídia que resguardadas as diferenças podemos ver nele o "amigo radiouvinte": "Desde a manhã até a noite, sem pausa, histórias povoam as ruas e os prédios. Articulam nossas existências ensinando-nos o que elas devem ser. 'Cobrem o acontecimento', ou seja, fazem deles as nossas legendas (legenda: aquilo que se deve ler e dizer). Apanhando desde o momento em que acorda pelo rádio (a voz é a lei), o ouvinte anda o dia inteiro pela floresta 
de narratividades jornalísticas, publicitárias, televisionadas, que de noite, ainda introduzem as suas últimas mensagens sob as portas do sono.”(p. 287) CERTEAU, Michel de. Maneiras de crer. In: . A invenção do cotidiano. Petrópolis: Vozes, 1994. p. 277-303.

${ }^{33}$ ALERTA, Laguna! In: ROMERO, Fernando (Org.). Cadernos da Laguna: A terra e a gente. n. 1, Fundação Catarinense de Cultura, s.d.. p. 18.

${ }^{34}$ ARENDT, Hannah. Entre o passado e o futuro. 3 ed. São Paulo: Perspectiva, 1992. p. 53.

${ }^{35}$ Segundo Pierre Bourdieu no mundo social os símbolos também comportam elasticidade, indeterminação e fluidez. Daí a procura por construir uma visão homogenizadora de percepção invariável. Para este autor, "esse elemento objetivo de incerteza - que é muitas vezes reforçado pelo efeito da categorização, podendo a mesma palavra englobar práticas diferentes - fornece uma base para a pluralidade de visões de mundo, também ela ligada à pluralidade de pontos de vista. E, ao mesmo tempo, uma base para as lutas simbólicas pelo poder de produzir e impor a visão de mundo legítima."(p. 161) BOURDIEU, Pierre. Espaço social e poder simbólico. In: Coisas ditas. São Paulo: Brasiliense, 1990. p. 149-168.

${ }^{36}$ GEERTZ, Clifford. A interpretação das culturas. Rio de Janeiro: Guanabara Koogan, 1989 (cop.), p. 149.

${ }^{37}$ PREFEITURA MUNICIPAL DE LAGUNA. Laguna: a natureza e o passado sempre presentes. (guia histórico e turístico da administração 1983-88). p. 08.

${ }^{38}$ PREFEITURA MUNICIPAL DE LAGUNA. Laguna: Três séculos de brasilidade. (Florianópolis): UFSC, 1982. p. 15.

${ }^{39}$ PREFEITURA MUNICIPAL DE LAGUNA. Laguna: o passado sempre presente. (folder s.d.). Bronislaw Baczko escreve que: "para garantir a dominação simbólica, é de importância capital o controle destes meios, que correspondem a outros tantos instrumentos de persuasão, pressão e inculcação de valores e crenças. É assim que qualquer poder procura desempenhar um papel privilegiado na emissão dos discursos que veiculam os imaginários sociais, do mesmo modo que tenta conservar um certo controle sobre os seus circuitos de difusão."(p. 313) BACZKO, Bronislaw. Imaginação social. In: Enciclopédia Einaudi. Lisboa: Imprensa nacional-Casa da Moeda. v. 5. 1995. p. 296-332. Ver também: HOBSBAWM, Eric. A produção em massa de tradições: Europa, 1870 a 1914. In: das tradições. Rio de Janeiro: Paz e Terra, 1984. p. 271-316.

${ }^{40}$ PREFEITURA MUNICIPAL DE LAGUNA. Laguna, venha viver esta emoção. (folheto turístico da administração 93-96).

${ }^{41}$ CERTEAU, Michel de. A invenção do cotidiano. Petrópolis: Vozes, 1994. p. 289.

${ }^{42}$ BOURDIEU, Pierre. Coisas ditas. São Paulo: Brasiliense, 1990. p. 162.

${ }^{43}$ PREFEITURA MUNICIPAL DE LAGUNA. Laguna: os paralelepípedos da velha cidade vão arrepiar. (folder turístico da administração 1993-96).

${ }^{44}$ Minha Laguna. Hino oficial da cidade, letra e música de Osmar Ferreira Cook. Lei n. 32 de 02 de setembro de 1975.

${ }^{45}$ O CORREIO. Laguna, 04 a 10 nov. 1995. p. 8.

${ }^{46}$ Este texto é o início de um artigo que homenageia alguns comerciantes locais, nem por isso deixa de assinalar a grandiosidade do passado lagunense. HOMENS que acreditaram e fizeram a Laguna. O Correio. Laguna, 28 out. a 02 nov. 1995. p. 5. 
${ }^{47}$ PREFEITURA MUNICIPAL DE LAGUNA. Laguna: Três séculos de brasilidade. (Florianópolis): UFSC, 1982. p. 15.

${ }^{48}$ DALL'ALBA, João L.(org.). Laguna antes de 1880: documentário. Florianópolis: Lunardelli/ UDESC, 1979. p. 10.

${ }^{49}$ Amélia Baungarten Baião. (Secretária de Educação da Pref. Municipal de Laguna) Entrevista concedida a João Batista Bitencourt. Laguna, 27 jun. 1996.

${ }^{50}$ João Manoel Vicente (radialista e assessor de imprensa da Pref. Municipal de Laguna). Entrevista concedida a João Batista Bitencourt. Laguna, 07 maio. 1996.

${ }^{51}$ Walter Benjamin escrevendo sobre a obra La recherche du temps perdu, diz que Marcel Proust não descreveu os acontecimentos de uma vida, mas recordações de quem os viveu. Para Benjamin, "um acontecimento vivido é finito, ou pelo menos encerrado na esfera do vivido, ao passo que o acontecimento lembrado é sem limites, porque é apenas uma chave para tudo o que veio antes e depois."(p. 37) BENJAMIN, Walter. A imagem de Proust. In: Magia e técnica, arte e politica. 7 ed. São Paulo: Brasiliense, 1994. p. 36-49.

${ }^{52}$ NORA. Pierre. Entre memória e história: A problemática dos lugares. Projeto história. São Paulo, n. 10, p. 7-28. dez. 1993. p. 15.

${ }^{53}$ Segundo Pierre Nora, para a história os lugares de memória "São bastiões sobre os quais se escora. Mas se o que eles defendem não estivesse ameaçado, não se teria, tampouco, a necessidade de construí-los. Se vivêssemos verdadeiramente as lembranças que eles envolvem, eles seriam inúteis. E se, em compensação, a história não se apoderasse deles para deformálos, transformá-los, sová-los e petrificá-los eles não se tornariam lugares de memória" (p. 13) NORA. Pierre. Entre memória e história: A problemática dos lugares. Projeto história. São Paulo, n. 10, p. 7-28. dez. 1993.

${ }^{54}$ BOURDIEU, Pierre. A economia das trocas lingüísticas. In: ORTIZ, Renato (org.). Pierre Bourdieu. 2 ed. São Paulo: Ática, 1994. p. 161.

${ }^{55}$ FOUCAULT, Michel. A ordem do discurso. São Paulo: Loyola, 1996. p. 09.

${ }^{56}$ Ibid. p. 9.

${ }^{57}$ PREFEITURA MUNICIPAL DE LAGUNA. Laguna/80: Historia, turismo y amistad. (guia turístico e histórico da administração 1977-83). p. 1. 